\title{
Surgical Gastrostomy With Mini Laparatomy Under Local Anesthesia: Analysis of 62 Cases
}

\section{Lokal Anestezi Altında Mini Laparotomi ile Cerrahi Gastrostomi: 62 Olgunun Analizi}

Cebrail Akyuz ${ }^{1}$,

'Haydarpasa Numune Training and Research Hospital, Department of General and Gastroenterological Surgery, Turkey

Gelis Tarihi/Received: 02 October 2018 Kabul Tarihi/Accepted: 03 January 2019

Address correspondence to: Cebrail Akyuz, HaydarpasaNumune Training and Research Hospital, Department of General and Gastroenterological Surgery, Turkey

e-posta: drcakyuz@hotmail.com

ORCID

Cebrail Akyuz

https://orcid.org/0000-0003-0917-9345

\begin{abstract}
Öz
Amaç: Obstrüktif tümörler, nöromuskuler hastalıklar, felç, serebral kanama gibi durumlarda genellikle beslenme amaçıı gastrostomi gerekir. Bu çalışmanın amacı, endoskop kullanımının kısıtlı olduğu durumlarda lokal anestezi altında uygulanabilen mini laparotomi ile cerrahi gastrostominin başarılı şekilde kullanımını tartısmaktır.

Hastalar ve Yöntemler: Ocak 2012 Aralık 2017 arasında cerrahi gastrostomi yapılan yetmiş beş hasta retrospektif olarak tarandı. Oral ve nasogastrik tüp kullanılamayan ve perkutan endoskopik gastrostomi yapılamayan 62 hastaya lokal anestezi altında Stamm gastrostomi prosedürü uygulandı. Bulgular: Hastaların yaş ortalaması 63.7 idi ve \% 83.9' u ASA IV'tü. Gastrostomi endikasyonunun \% 51.6' sını tümör obstrüksiyonu, \% 17.7' sini nöromüskuler hastalıklar, \% 16.6'sını ise inme ve serebral kanamalar, \% 1.6'sını özafagus yaralanması, \% 12.9'unu metastatik tümörler ve hipoksikensefalopati oluşturmaktaydı. Ortalama ameliyat süresi $36 \pm 12.8$ dakika idi. İşleme bağlı hastane içi morbidite ve mortalite oranları düşüktü (sırasıyla; \% 16.2- \% 14.5).

Sonuç: Lokal anestezi altında mini laparotomi ile Stamm gastrostomi, perkütan ve endoskopik yaklaşımların uygulanamadığı durumlarda etkili bir alternatiftir. Yüksek riskli hastalarda kısa ameliya
\end{abstract} süresi, düşük morbidite ve mortalite oranları ile güvenli bir şekilde uygulanabilir. .

Anahtar Kelimeler: Cerrahi gastrostomi, komplikasyon, mortalite, mini laparatomi, lokal anestezi

\section{Abstract}

Aim: Feeding gastrostomy is generally needed in the cases of oropharnyngeal dysphagia. The objective of this study is to analyze the use of surgical gastrostomy with mini laparatomy under local anaesthesia in situations where endoscopic procedure is not possible.

Patients Methods: Seventy-five patients in whom surgical gastrostomy (SG) procedure was performed were analyzed retrospectively from January 2012 to December 2017. Stamm gastrostomy was performed in 62 patients in whom oral and nasogastric tube feeding could not be given and percutaneous endoscopic gastrostomy could not be performed by using Stamm technique with internal bolster mushroom tube under local anesthesia.

Results: A mean age of the patients are 63.7 years old and $83.9 \%$ of them were ASA IV. The indications for gastrostomy were tumour obstruction, neuromuscular diseases, paralysis and cerebrovascular bleeding, oesophageal injury, metastatic tumours and hypoxic encephalopathy in 51.6, 17.7, and 16.6, 1.6 and $12.9 \%$ respectively. The mean operation duration was $34 \pm 12.8$ minutes. Procedure-dependent hospita morbidity and mortality were low (\% $16.2-\% 14.5$, respectively).

Conclusion: Stamm gastrostomy with mini laparatomy under local anaesthesia is an effective alternative in situations where percutaneous or endoscopic procedures cannot be done. It can be performed in highrisk patients safely due to its short operation time, low morbidity and mortality.t can be performed in high-risk patients safely due to its short operation time, low morbidity and mortality.

Keywords: Surgical gastrostomy, complication, mortality, mini laparatomy, local anaesthesia

\section{INTRODUCTION}

Enteral feeding is important in care and treatment of patients with a functionally active gastro intestinal system (GIS) to provide energy need, protect GIS flora and prevent bacterial translocation $(1,2)$. The way of feeding is gastrostomy or jejunostomy in the patients who have an intact GIS tract but, for some reasons, unable to take orally (3). Gastrostomy can be performed by means of endoscopic, radiologic or surgical methods (4). Percutaneous endoscopic Cite this article as: Akyüz C. Surgical Gastrostomy with Mini Laparatomy Under Local Anesthesia: Analysis of 62 Cases. Selcuk Med J 2020;36(1): 18-21 gastrostomy (PEG) is a simple, cheap and of a very low complication risk procedure, which does not need general anaesthesia $(1,5,6)$. Surgical gastrostomy (SG) is an invasive procedure and frequently necessitates general anaesthesia (6). Today, PEG is known to be safer in patients with nutrition problems than SG. SG is an alternative method where endoscopic access into the stomach is difficult (7). Especially severe respiratory insufficiency might restrict the use of endoscopy (8). SG can be 
performed by either laparatomy or laparoscopy (9).

We analyzed indications and results of SG performed successfully under local anaesthesia by means of mini laparotomy at a state training and research hospital.

\section{PATIENTS AND METHODS}

The study was approved by Regional Ethical Committee (HNH-KAEK 2018/KK/19). Written informed consent was taken from the conscious patients and from the official representatives of unconscious patients. The study was conducted in accordance with Helsinki Declaration.

Seventy-five patients in whom SG procedure was performed were analyzed retrospectively from January 2012 to December 2017. Gastrostomy procedures were performed by a surgeon working in the palliative care unit. Surgical gastrostomy for enteral feeding was performed in all the patients. The patients with abdominal operation history were not operated under local anaesthesia and thirteen patients were excluded as they needed surgical procedure under general anaesthesia. Local anaesthesia was achieved by administering $10 \mathrm{ml}$ of $1 \%$ lidocaine $\mathrm{HCL}$ and $2 \%$ prilocaine $\mathrm{HCL}$ mixture. No sedation was used in any of the patients. The surgical gastrostomy was performed in 62 patients by using Stamm technique with internal bolster mushroom tube (8). Making a 4 $\mathrm{cm}$ epigastric median incision, the greater curvature of the stomach was found and pulled out of the incision. Anterior wall was incised $5 \mathrm{~mm}$, gastrostomy tube was inserted through it and fixed with double purse-string non-absorbable $3 / 0$ suture. Then the free tip of the tube was pulled out of the abdominal wall by making a 3-4 $\mathrm{mm}$ skin and fascia incision three $\mathrm{cm}$ left lateral to median one. The technique was not modified such as omentum was not wrapped around the tube nor the stomach was not fixed to the abdominal wall. Antibiotic and thromboemboli prophylaxis were done in all patients with a single dose of $1 \mathrm{~g}$ of cephazolin IV and low molecular weight heparine, which was given pre and post operatively. Enteral feeding via gastrostomy tube was started at the post operative 24th hour under the control of a nutritionist.

Age, gender, indications for SG, ASA (American Society of Anaesthesiology) scores, local and systemic complications, hospital stay period and post operative 30-day mortality were recorded. Statistical analysis was done by using SPSS 16.0 program (SPSS for Windows, 2008, SPSS Inc., Chicago, Illinois, ABD)
Table 1. Patient demographics and indications for surgical gastrostomy

\begin{tabular}{lcc}
\hline Age (years) & $\mathbf{6 3 . 7 0 \pm 1 2 . 0}$ & $\mathbf{( 2 6 - 9 1 )}$ \\
Parameters & Number (n) & Percentage (\%) \\
\hline Gender & 43 & 69.3 \\
$\quad$ Male & 19 & 30.7 \\
$\quad$ Female & 10 & 16.1 \\
ASA III & 52 & 83.9 \\
ASA IV & & \\
Indication & 32 & 51.6 \\
$\quad$ Obstructing tumors & 13 & 20.9 \\
$\quad$ Head-neck & 19 & 30.7 \\
$\quad$ Esophagus & 11 & 17.7 \\
Neuromuscular diseases & 8 & 12.9 \\
$\quad$ AML & 3 & 4.8 \\
$\quad$ DMD & 10 & 16.2 \\
Paralysis or CVB & 1 & 1.6 \\
Trauma & 5 & 8.1 \\
Metastatic tumors & 3 & 4.8 \\
Hypoxic encephalopathy & &
\end{tabular}

ASA: American Society of Anesthesiology, AML: Amyotrophic Lateral Sclerosis, DMD: Duchenne's Muscular Dystrophy CVB: cerebrovascular bleeding

\section{RESULTS}

Stamm gastrostomy was performed in 62 patients of whom $43(69.3 \%)$ was male and 19 (30.7) was female. The mean age was $63.7 \pm 12.30$ (26-91) years. Generally, the risk of anaesthesia was high as $83.9 \%(n=52)$ of the patients had ASA IV score. The indication of gastrostomy was the obstruction (51.6\%, $\mathrm{n}=32$ ) due to head, neck and oesophageal tumours in more than half of the patients. Other indications were neuromuscular disorders (Lateral Amyotrophic Sclerosis and Duchenne's Muscular Dystrophy) in 11 $(17.7 \%)$; paralysis or cerebrovascular bleeding in 10 (16.6\%); traumatic oesophageal injury in 1 (1.6\%); metastatic tumours in $5(8 \%)$ (3 patients with breast cancer metastases and 2 with lung cancer metastases to oesophagus) and hypoxic encephalopathy in 3 patients $(4.8 \%)$ (Table 1$)$.

The mean operation time was $34 \pm 12.8$ minutes. Procedure-dependent hospital morbidity was seen

Table 2. The results and complications in surgical gastrostomy patients

\begin{tabular}{lcc}
\hline $\begin{array}{l}\text { Operation Time } \\
\text { (minutes- mean } \pm \text { SD) }\end{array}$ & \multicolumn{2}{c}{$34 \pm 12.8$} \\
Complications & Number (n) & Percentage (\%) \\
\hline Peristomal leakage & 4 & 6.4 \\
Surgical area İnfection & 3 & 4.8 \\
Obstruction of drain & 1 & 1.6 \\
Drain Displacement & 1 & 1.6 \\
Eventration & 1 & 1.6 \\
Total & 10 & 16.1 \\
\hline
\end{tabular}


Table 3. Causes of mortality

\begin{tabular}{lcc}
\hline & Number (n) & Percentage (\%) \\
\hline Aspiration pneumonia & 4 & 6.4 \\
Myocardial infarction & 2 & 3.2 \\
Pulmonary emboli & 2 & 3.2 \\
Miscellaneous & 1 & 1.6 \\
Total & 9 & 14.5 \\
\hline
\end{tabular}

in 10 patients (16.2\%). The most frequent morbidity causes were peristomal leakage $(n=4,6.4 \%)$ and surgical area infections $(n=3,4.8 \%)$. There was eventration in one patient and it was treated conservatively. The tube was displaced in one patient at the 17th day and obstructed in one at the 23th day, respectively; the tube was replaced by a bigger size one in both (Table 2). The mortality within the first 30 days following surgery (30-day mortality) was seen in $9(14.5 \%)$ patients, causes of which were aspiration pneumonia in $4(6.4 \%)$, myocardial infarction in 2 $(3.2 \%)$, pulmonary emboli in $2(3.2 \%)$. The cause could not be found in $1(1.6 \%)$ patient (Table 3). Stamm gastrostomy under local anaesthesia was performed in 62 patients of palliative care unit in whom PEG could not been succeeded. The mean operation time was $34 \pm 12.8$ minutes and 30-day mortality was nine.

\section{DISCUSSION}

Enteral feeding provides important advantages compared to parenteral nutrition in the patients with a functioning GIS but who cannot take nutrients orally (10). ESPEN (The European Society for Clinical Nutrition and Metabolism) suggests PEG in such patients for feeding if it will be continued more than 2 to 3 weeks (11). PEG was found superior to SG because of both its low cost and complication and low mortality rates by the studies conducted in last 20 years $(12,13)$. In presence of obstructing tumours in head, neck or upper GIS, presence of neuromuscular disorders which necessitate continuous non-invasive ventilator use and in situations where stomach is cannot be accessed endoscopically, surgical or radiologic techniques come into mind to place a feeding tube (7). Though radiologic techniques have been reported being used with success in the literature, it is not used widely in our country.

Being performed under local anaesthesia and using mini-laparotomy, Stamm gastrostomy is a proven, important option, compared to other methods. Its success rate is high. Its another advantage is providing exploration chance of peritoneal cavity, even if limited, in the patients with previous history of surgery (14-16).

Surgical gastrostomies were more effective compared to endoscopic and radiologic methods but mortality and complication rates were very high in studies conducted in the past. SG dependent morbidity and mortality varies between $4-74 \%$ and $2.5-22 \%$, respectively (17-20). These studies were retrospective mostly and involved a heterogeneous patient group. The patient demographics and heterogeneity made comparison of the results difficult. The follow up of every patient was not the same. Similar to the literature, our study was also retrospective and heterogeneity was frequent among the patient which makes our results disadvantageous. Oliveira et al. found the complication rates $27.8 \%$ in open surgery and $12.1 \%$ in PEG group; and the $30-$ day early mortality $33.3 \%$ in open surgery and $13.4 \%$ in PEG groups, respectively (13). They did not find significant difference between the groups statistically and it was related to insufficient number of the patients in surgery group. Also, Bergstom et al. reported that the complication rate in the patients with surgical feeding tube placement was similar to that of PEG (21).We had a low morbidity rate in our study (16.1\%).

The most frequent complications following SG are peristomal leakage and infection, surgical area infection and 30-day early mortality unrelated to procedure $(8,12,18)$. Peristomal leakage/infection and surgical area infection involved an important ratio of the morbidity. The mortality was seen in 9 patients; 4 were procedure-related and 5 were procedure-unrelated. Although our overall mortality rate of $14.5 \%$ seemed high, procedure-related mortality was only $6.4 \%$. A few studies reported such severe complications as cardiopulmonary arrest, haemorrhage, perforation, necrotizing fasciitis and tumour seeding following PEG $(5,10,22)$. We did not see such severe complications in our study which might be related to lesser patient number in whom SG is performed compared to that of endoscopic PEG.

The mean operation time is relatively longer for laparoscopic gastrostomy and relatively shorter for PEG in literature $(6,9,23)$. The mean operation time in our study was $34 \pm 12.8$ minutes and it was relatively very short considering these risky patients. Concerning the pearls and the pitfalls of the technique, it does need neither general anaesthesia nor sedation, can be used practically. Its pitfall is insufficient relaxation of the muscle which can result in elongation of the operation duration. 


\section{CONCLUSION}

As a result, considering the high ASA scores, severity of the co-morbid diseases and undesired results, in a selected group of patients, gastrostomy under local anaesthesia by using mini laparotomy seems safer. It is effective with its shorter operation time in critically ill patients.

Conflict of interest: Author declares that there is no conflict of interest between the authors of the article.

Financial conflict of interest: Author declares that he did not receive any financial support in this study.

Address correspondence to: Cebrail Akyuz, Department of General and Gastroenterological Surgery, Haydarpasa Numune Training and Research Hospital, Tibbiye Cad. No: 23, 34668, Usküdar/lstanbul, Turkey.

Phone: +905054549902

E-mail:drcakyuz@hotmail.com

\section{REFERENCES}

1. Beaver ME, Myers JN, Griffenberg L, et al. Percutaneous fluoroscopic gastrostomy tube placement in patients with head and neck cancer. Arch Otolaryngol Head Neck Surg 1998;124:1141-4.

2. Kırdak T, Özgüç $H$, Keskin $M$, et al. Our experience on feeding ostomies. Ulus Cerrahi Derg 2008;24:200-4.

3. Shellito PC, Malt RA. Tube gastrostomy technique and complications. Ann Surg 1985;201:180-5.

4. Tucker AT, Gourin CG, Ghegan MD, et al. 'Push' versus 'pull' percutaneous endoscopic gastrostomy tube placement in patients with advanced head and neck cancer. Laryngoscope 2003;113:1898-902.

5. Lucendo AJ, Friginal-Ruiz AB. Percutaneous endoscopic gastrostomy: An update on its indications, management, complications, and care. Rev Esp Enferm Dig 2014;106:52939.

6. Bravo JG, de E, Kondo A, de Moura DT, et al. Percutaneous endoscopic versus surgical gastrostomy in patients with benign and malignant diseases: A systematic reviewand meta-analysis. Clinics (Sao Paulo) 2016;71:169-78.

7. Kwon RS, Banerjee S, Desilets D, et al. Enteral nutrition access devices. Gastrointest Endosc 2010;72:236-48.

8. Zickler, RW, Barbagiovanni JT, Swan, KG. A simplified open gastrostomy under local anaesthesia. Am Surg 2001;67:8068.

9. Matsutani T, Nomura T, Hagiwara $\mathrm{N}$, et al. Comparison of postoperative pain following laparoscopic versus open gastrostomy/jejunostomy in patients with complete obstruction caused by advanced esophageal cancer. J Nippon MedSch 2016;83:228-34.

10. Yuruker S, Koca B, Karabicak I, et al. Percutaneous endoscopic gastrostomy: Technical problems, complications, and management. Indian J Surg 2015;77:1159-64.

11. Löser $C$, Aschl $G$, Hébuterne $X$, et al. ESPEN guidelines on artificial enteral nutrition-percutaneous endoscopic gastrostomy (PEG). Clin Nutr 2005;24:848-61.

12. Stiegmann GV, Goff JS, Silas D, et al. Endoscopic versus operative gastrostomy: Final results of a prospective randomized trial. Gastrointest Endosc 1990;36:1-5.
13. Oliveira GP, Santos CA, Fonseca J. The role of surgical gastrostomy in the age of endoscopic gastrostomy: A 13 years and 543 patients retrospective study. Rev Esp Enferm Dig 2016;108:776-9.

14. Bach J.R, Gonzalez M, Sharma A, et al. Open gastrostomy for noninvasive ventilation users with neuromuscular disease. Am J Phys Med Rehabil 2010;89:1-6.

15. Saitua F. Acuña R, Herrera, P. Percutaneous endoscopic gastrostomy: thetechnique of choice?. J Pediatr Surg 2003;38:1512-5.

16. Faria GR, Taveira-Gomes A. Open gastrostomy by minilaparotomy: A comparative study. Int J Surg 2011;9:263-6.

17. Souza EC. Surgical gastrostomy based on endoscopic concepts. Arq Bras Cir Dig 2016;29:50-2.

18. Ljungdahl $M$, Sundbom $M$. Complication rate lower after percutaneous endoscopic gastrostomy than after surgical gastrostomy: A prospective, randomized trial. Surg Endosc 2006;20:1248-51.

19. Ho HS, Ngo H. Gastrostomy for enteral access. A comparison among placement by laparotomy, laparoscopy, and endoscopy. Surg Endosc 1999;13:991-4.

20. Wollman B, D'Agostino HB, Walus-Wigle JR, et al. Radiologic, endoscopic, and surgical gastrostomy: An institutional evaluation and meta-analysis of the literature. Radiology 1995; 197:699-704.

21. Bergstrom LR, Larson D, Zinsmeister AR, et al. Utilization and outcomes of surgical gastrostomies and jejunostomies in an era of percutaneous endoscopic gastrostomy: A population based study. Mayo Clin Proc 1995;70:829-36.

22. Rahnemai-Azar AA, Rahnemaiazar AA, Naghshizadian R, et al. Percutaneous endoscopic gastrostomy: Indications, technique, complications and management. World J Gastroenterol 2014;20:7739-51.

23. Mizrahi I, Garg M, Divino CM, et al. Comparison of laparoscopic versus open approach to gastrostomy tubes. JSLS 2014;18:28-33. 